\title{
FACTORS ASSOCIATED WITH OBESITY AND OVERWEIGHT IN SCHOOL-AGED CHILDREN
}

\author{
Márcia Christina Caetano de Souzaㄹ, Jacqueline Domingues Tibúrcio², Juliana Mara Flores Bicalho ${ }^{3}$, Heloiza \\ Maria de Siqueira Rennó ${ }^{4}$, Jacqueline Souza Dutra ${ }^{5}$, Luis Gustavo Campos ${ }^{6}$, Eduardo Sérgio Silva
}

\footnotetext{
${ }^{1}$ Ph.D. in Nursing. Adjunct Professor, Nursing Program, Universidade Federal de São João del-Rei (UFSJ). Divinópolis, Minas Gerais, Brazil. E-mail: marciachristinacs@gmail.com

${ }^{2}$ M.Sc. in Statistics. Assistant Professor, UFSJ. Divinópolis, Minas Gerais, Brazil. E-mail: jacqueline.d.tiburcio@gmail.com

${ }^{3}$ B.Sc. in Nutrition. Nutritionist, Municipal Health Secretary, Divinópolis, Minas Gerais, Brazil. E-mail: nutricaosemusa@gmail. com

${ }^{4}$ M.Sc. in Nursing. Assistant Professor, Nursing Program, UFSJ. Divinópolis, Minas Gerais, Brazil. E-mail: heloizarenno@ufsj. edu.br

${ }^{5}$ Undergraduate Nursing student, UFSJ. Divinópolis, Minas Gerais, Brazil. E-mail: jacquelinesd@hotmail.com

${ }^{6}$ B.Sc. in Nursing. Resident in Obstetric Nursing at Hospital Sofia Feldman. Belo Horizonte, Minas Gerais, Brazil. E-mail: Ig1990@ hotmail.com

${ }^{7}$ Ph.D. in Biology. Adjunct Professor, UFSJ. Divinópolis, Minas Gerais, Brazil. E-mail: eduardosergiosilva@gmail.com
}

\begin{abstract}
To assess the factors associated with excess weight (overweight/obese) in school children enrolled in the public education network in Divinópolis, Minas Gerais, Brazil. Cross-sectional study with 1187 children between 6 and 14 years of age from municipal schools in Divinópolis, Minas Gerais. The prevalence of obesity and overweight was calculated based on the parameters of the World Health Organization, using the WHO Anthro-Plus Program. Logistic regression was used to identify the variables associated with excess weight, at a significance level of $5 \%$. A prevalence of $24.4 \%$ of excess weight was identified. Family income and maternal education were determinants of overweight in the study population $(\mathrm{p}<0.05)$. Excess weight was configured as an important health problem among the students. The public power needs to implement intersectoral measures with a view to the prevention and reduction of the prevalence of overweight and obesity among school-aged children.
\end{abstract}

DESCRIPTORS: Obesity. Overweight. Child. Adolescent. Schools.

\section{FATORES ASSOCIADOS À OBESIDADE E SOBREPESO EM ESCOLARES}

RESUMO: Avaliar os fatores associados ao excesso de peso (sobrepeso/obeso) em escolares matriculados no ensino fundamental da rede pública de ensino de Divinópolis, Minas Gerais, Brasil. Estudo transversal com 1187 escolares de seis a 14 anos de idade da rede municipal de ensino de Divinópolis, Minas Gerais. Prevalência de obesidade e sobrepeso foi calculada a partir dos parâmetros da Organização Mundial de Saúde, utilizando-se o Programa WHO Anthro-Plus. Regressão logística foi usada para identificação das variáveis associadas ao excesso de peso, considerando um nível de significância de $5 \%$. Foi identificada prevalência de $24,4 \%$ de excesso de peso. Renda familiar e escolaridade materna foram determinantes do excesso de peso na população do estudo ( $<<0,05)$. $O$ excesso de peso configurou-se como importante problema de saúde entre os escolares. Medidas de ordem intersetorial necessitam ser implementadas pelo poder público, visando prevenir e reduzir as prevalências de sobrepeso e obesidade entre os escolares.

DESCRITORES: Obesidade. Sobrepeso. Criança. Adolescente. Instituições acadêmicas.

\section{FACTORES ASOCIADOS A LA OBESIDAD Y EL SOBREPESO EN LA ESCUELA}

RESUMEN: Evaluar los factores asociados con el exceso de peso (sobrepeso/obesidad) en los niños matriculados en una escuela primaria de la red pública de Divinópolis, Minas Gerais, Brasil. Estudio transversal con 1.187 escolares de 6 a14 años de edad de la red municipal de enseñanza de Divinópolis, Minas Gerais. La prevalencia de la obesidad y el sobrepeso se calculó a partir de los parámetros de la Organización Mundial de la Salud, mediante el Programa WHO Anthro-Plus. Se utilizó la regresión logística para identificar las variables asociadas con el exceso de peso, considerando un nivel de significación del 5\%. Se observó una prevalencia de $24,4 \%$ de sobrepeso. Los ingresos familiares y la educación materna fueron determinantes con sobrepeso en la población estudiada $(p<0,05)$. El exceso de peso fue configurado como el principal problema de salud en escolares. Medidas de orden intersectorial deben ser implementadas por el gobierno con el fin de prevenir y reducir la prevalencia del sobrepeso y la obesidad en la escuela.

DESCRIPTORES: Obesidad. Sobrepeso. Niño. Adolescente. Instituciones académicas. 


\section{INTRODUCTION}

Obesity and overweight are defined as the abnormal accumulation of body fat, which can entail severe implications for people's health. They represent a severe public health problem, mainly due to the global trend towards increased prevalence rates and the impact they cause in society. Around the world, in 2008, more than 1.4 billion adults suffered from these problems and, in 2010, approximately 40 million children over five years of age were overweight. ${ }^{1}$

In Brazil, the number of overweight schoolaged children is alarming. Data for 2009 from the Brazilian Institute of Geography and Statistics (IBGE), in a study involving freshman students in all Brazilian state capitals, demonstrate that obesity and overweight were the mean nutritional problems identified. The prevalence of obese students corresponded to $7.2 \%$. The highest proportions were evidenced in Porto Alegre with 10.5\%, Rio de Janeiro and Campo Grande, each with 8.9\%. In the capital of the state of Minas Gerais, $7.2 \%$ of school-aged children were obese. ${ }^{2}$

The condition of overweight and obesity involves multiple determinants. One of the factors associated is early weaning, as opposed to breastfeeding for six months or longer, which is identified as a protection factor. ${ }^{3-4}$ The family income, socioeconomic condition, maternal education level, ownership of consumption goods, living in urban areas and maternal overweight are also related with excess weight in children. ${ }^{5-9}$ Other factors that stand out as determinants for these problems are watching TV for more than three hours per day, consumption of sweets four or more times per week, short length of sleep and studying in private schools. $5,7,9-11$

The relevance of family antecedents for cardiovascular diseases has been discussed in the determination of obesity and overweight among children, indicating the need to pay more attention to that group. ${ }^{12}$ Another important factor in the determination of the children's overweight is the parents' education level. It is believed that a higher parental education level can contribute to better care for the child, with a view to health maintenance as well as the encouragement of physical exercise and the consumption of healthy foods. ${ }^{13}$

The child's emotional behavior towards food has also been studied in the identification of factors associated with overweight in that group. In Chile, it was demonstrated in a study that certain food-related behaviors of the child, such as the act of eating rapidly, are associated with obesity and overweight, indicating the importance of psychosocial interventions in that group. ${ }^{14}$

It is highlighted that overweight in children negatively influences their health. Obese children have a greater chance of becoming obese adolescents. ${ }^{15}$ The presence of cutaneous folds, a clear characteristic of overweight children, has been indicated as a significant factor associated with arterial hypertension in this age group. ${ }^{16}$ Higher prevalence rates of arterial hypertension have been observed among obese children. ${ }^{17}$

In addition, the indirect financial impact of these problems in society is mentioned, as secondary illnesses imply higher spending on medical care and the use of health services, entailing higher public expenses. ${ }^{18}$

Thus, in view of the importance and impact of obesity and overweight among children and adolescents, it is relevant to develop studies that provoke further reflection on the theme. Therefore, the objective in this research is to assess the factors associated with excess weight (overweight/ obesity) in school-aged children in the municipal public education network in Divinópolis, Minas Gerais, Brazil.

\section{METHOD}

A cross-sectional, epidemiological and analytic study was developed. The research was undertaken at 14 municipal public schools in the education network of Divinópolis, a city in the West of Minas Gerais. In total, 1,187 children between 6 and 14 years of age constituted the study universe, including urban and rural schools. The children who adhered to the research represent a sample of students in the network.

The number of students enrolled in the public education network ( $1^{\text {st }}$ to $9^{\text {th }}$ year) in the first semester of 2011 corresponded to 10,656 students, distributed across 36 schools. The schools are spread across 11 regions. The sample dimensioning considered cluster sampling. The selection aimed to guarantee the representativeness of the number of schools and students per region. Thus, initially, a number proportional to the number of schools per region was drafted, considering the following stratification: one school drafted in regions with four or less schools, two schools in regions with more than four and eight or less schools, and three schools drafted in regions with 
more than eight schools. At the selected schools, a meeting was held with parents, responsible caregivers, children and adolescents, during which the project was explained in accessible language, possible doubts were clarified and the school-aged children were invited to participate. Next, both the parents/responsible caregivers and the children and adolescents who accepted to participate signed the informed consent form. In the sample calculation, the minimum number of children who participate in the study was 1098, considering a prevalence level of $15 \%$ of children with excess weight, obtained from the pilot study, a $2 \%$ error margin and a 95\% significance level.

Demographic, socioeconomic and dietary habit data were collected by means of a questionnaire applied to the students' parents and/or responsible caregivers. Anthropometric data used for the nutritional assessment were obtained by weighing the students once using digital Filizola PL-180 platform scales and by checking the height using the average of three measures on a portable stadiometer Altura Exata.

The response (dependent or outcome) variable is the excess weight. School-aged students with overweight or obesity were considered as excess weight. The explanatory (independent) variables or factors were selected in view of the following dimensions: personal characteristics (gender, skin color), socioeconomic markers (family income, participation in family allowance program, ownership of the place of residence, mother's education level and tap water at the place of residence), habits (physical exercise, consumption of home-made remedies, most used health service) and location of the school. The mutual correlations were determined using Spearman's correlation coefficient.

For the nutritional assessment, the World Health Organization's program called WHO AnthroPlus was used, establishing the Body Mass Index (BMI) per age as the assessment index, classifying children with low BMI, eutrophic, overweight or obese, according to the OMS curves from 2007. The BMI was calculated by means of the formula Weight/Height, ${ }^{2}$ being the weight expressed in kilograms and the height in meters. The parameters used to classify the nutritional status with the BMI were low BMI when $\mathrm{z}$-score $<-2$, eutrophic when $\mathrm{z}$-score $>-2$ and $<+1$, overweight when $\mathrm{z}$-score $>+1$ and $<+2$ and obesity when $z$-score $\geq+2$, according to the cut-off points of the Food and Nutritional Surveillance. ${ }^{19-20}$
The research data were validated, entered twice and processed in Microsoft Office Excel 2007. For the statistical analysis, the Statistical Package for the Social Sciences (SPSS) 17.0 was used. Univariate binary logistic regression analysis was applied and variables with a significance probability of -.20 or less were used as co-variables in the multivariate model. In the final model, co-variables with a significance level below $5 \%$ were considered significant. The model adjustment was verified using Hosmer-Lemeshow's statistics and log likelihood. ${ }^{21}$

Approval for the research project was obtained from the Research Ethics Committee of the Fundação Educacional de Divinópolis/Universidade do Estado de Minas Gerais (FUNEDI/UEMG), under opinion 56/2009. Only those students who signed the Informed Consent Form together with their parents or responsible caregivers participated. This study complies with the regulatory standards for research involving human beings, National Health Council Resolution 196/96.

\section{RESULTS}

The assessment showed that $24.4 \%$ $(290 / 1,187)$ of the school-aged children suffered from overweight. Tables 1 and 2 display the univariate analysis results of the behavioral and socioeconomic factors associated with excess weight. It is highlighted that, due to the information lost during the data collection, the number of observation differs for some variables. In table 1 , the participants whose family indicated the habit to consume remedies had a 1.33 (1.00 to 1.78) times higher chance of suffering from excess weight when compared to the students without that habit, at the limit of the statistical significance $(p=0.051)$. The co-variable type of health service attended most (primary care: health clinic, family health strategy or pharmacy; and secondary care: hospital or emergency care) was not statistically associated with overweight ( $\mathrm{p}>0.05$ ).

In table 2 , it is shown with a $95 \%$ confidence level that school-aged children without a family allowance have a 1.68 (1.24 to 2.28) times higher chance of overweight than children with this allowance. Participants whose families gain an income of two or three minimum wages have twice as high a chance $(\mathrm{OR}=2.23 \mathrm{CI}=1.34$ till 3.72) of excess weight than children in families gaining less than one minimum wage. For children in families gaining three or more minimum wages, this chance increases to 2.90 (1.69 to 4.96) times higher than children in families gaining less than one minimum wage. 
Children whose mothers have more than eight years of study have a $1.62(1.19-2.19)$ times higher chance of overweight than mothers with eight years or less of education. The co-variables ownership of place of residence and tap water showed no statistically significant association with excess weight.

Table 1 - Association between behavioral factors and excess weight among school-aged children in Divinópolis-MG, 2011

\begin{tabular}{|c|c|c|c|c|c|}
\hline \multirow{2}{*}{ Variable } & \multicolumn{2}{|c|}{ Excess weight } & \multirow{2}{*}{ p-value* } & \multirow{2}{*}{ OR } & \multirow{2}{*}{$95 \% \mathrm{CI}(\mathrm{OR})$} \\
\hline & Yes n $(\%)$ & No $n(\%)$ & & & \\
\hline \multicolumn{6}{|l|}{ Gender (n=1187) } \\
\hline Female & $147(24.1)$ & $463(75.9)$ & & 1 & \\
\hline Male & $143(24.8)$ & $434(75.2)$ & 0.784 & 1.04 & $0.80-1.35$ \\
\hline \multicolumn{6}{|c|}{ Physical exercise $(\mathrm{n}=1058)$} \\
\hline Yes & $88(23.0)$ & $295(77.0)$ & & 1 & \\
\hline No & $164(24.3)$ & $514(75.7)$ & 0.628 & 1.08 & $0.80-1.44$ \\
\hline \multicolumn{6}{|c|}{ Health service $(\mathrm{n}=1134)$} \\
\hline Primary care & $162(22.9)$ & $544(77.1)$ & & 1 & \\
\hline Secondary care & $115(27.8)$ & $299(72.2)$ & 0.070 & 1.29 & $0.98-1.71$ \\
\hline \multicolumn{6}{|c|}{ Habit of homemade remedies $(n=1120)$} \\
\hline Yes & 85 (21.3) & $314(78.7)$ & & 1 & \\
\hline No & $195(26.5)$ & $540(73.5)$ & 0.051 & 1.33 & $1.00-1.78$ \\
\hline
\end{tabular}

* Pearson's chi-square test.

Table 2 - Association between socioeconomic factors and excess weight among school-aged children in Divinópolis-MG, 2011

\begin{tabular}{lccccc}
\hline \multirow{2}{*}{ Variable } & \multicolumn{2}{c}{ Excess weight } & \multirow{2}{*}{ p-value* } & OR & 95\%CI (OR) \\
\hline Family allowance (n=1170) & No $\mathbf{n}(\%)$ & -ve & & 1 & \\
Yes & $68(18.3)$ & $303(81.7)$ & & 1.68 & $1.24-2.28$ \\
No & $219(27.4)$ & $580(72.6)$ & 0.001 & & \\
Family income (n=1172) & & & & 1 & \\
$<1$ minimum wage & $19(12.8)$ & $129(87.2)$ & & \\
2 to 3 minimum wages & $174(24.8)$ & $529(75.2)$ & 0.002 & 2.23 & $1.34-3.72$ \\
$\geq 3$ minimum wages & $96(29.9)$ & $225(70.1)$ & $<0.001$ & 2.90 & $1.69-4.96$ \\
House (n=1176) & & & & & \\
Rented/Occupied & $82(21.8)$ & $294(78.2)$ & & 1 & \\
Self-owned & $211(26.0)$ & $599(74.0)$ & 0.120 & 1.26 & $0.94-1.69$ \\
Tap water (n=1173) & & & & & \\
No & $28(21.9)$ & $100(78.1)$ & & 1 & \\
Yes & $258(24.7)$ & $102(75.3)$ & 0.480 & 1.17 & $0.75-1.82$ \\
Mother's education (n=956) & & & & & \\
Less than 8 years of study & $127(20.7)$ & $488(79.3)$ & & 1 & \\
More than 8 years of study & $101(29.6)$ & $240(70.4)$ & 0.002 & 1.62 & $1.19-2.19$ \\
\hline
\end{tabular}

* Pearson's chi-square test.

Table 3 shows the result of the multivariate analysis to assess the association between excess weight and the co-variables considered. As observed, school-aged children whose mothers had more than eight years of education had a 1.51 (1.10-2.08) times higher chance of suffering from excess weight $(p=0.010)$ when compared to students whose mothers had eight years of less of education and, in addition, school-aged children with a family income of three minimum wages or more had a 2.0 (1.09-3.67) times higher chance of excess weight $(p=0.025)$ when compared to children whose family income was less than one minimum wage. 
Table 3 - Final multivariate logistic regression model of excess weight and associated factors among school-aged children in the city of Divinópolis-MG, 2011

\begin{tabular}{|c|c|c|c|c|}
\hline Variable & Model coefficient * & OR & 95\%CI (OR) & p-value \\
\hline \multicolumn{5}{|c|}{ Mother's education $(\mathrm{n}=956)$} \\
\hline$\leq 8$ years of education & & 1 & & \\
\hline$\geq 8$ years of education & 0.415 & 1.51 & $1.10-2.08$ & 0.010 \\
\hline \multicolumn{5}{|l|}{ Family income $(n=1206)$} \\
\hline$<1$ minimum wage & & 1 & & \\
\hline 2 a 3 minimum wages & 0.538 & 1.71 & $0.97-3.02$ & 0.064 \\
\hline$\geq 3$ minimum wages & 0.694 & 2.00 & $1.09-3.673$ & 0.025 \\
\hline
\end{tabular}

* Model adjustment: Hosmer Lemeshow=0.735 and -2 Log-likelihood=1026,80.

\section{DISCUSSION}

Overweight is a severe problem that affects population and can cause cardiovascular diseases, arterial hypertension, respiratory problems, diabetes, dislipidemias and some types of tumors, among other disorders. The more intense and early its emergence, the greater the risk of persistence and the more severe the associated comorbidities. It is highlighted that excess weight in childhood and adolescence predisposes to several psychosocial complications as, often, it comes with social isolation and distancing from activities due to discrimination and reduced acceptance of the subject in society. In addition to these severe consequences, excess weight is considered the most increasing disease all over the world. ${ }^{22-23}$

In this study, the prevalence rate of overweight observed in the participants corresponded to $24.4 \%$, below the Brazilian average of $47.8 \%$ according to recent IBGE data. ${ }^{24}$ In Pernambuco, in a study involving children and adolescents, using the information available in the Pesquisa Estadual de Saúde e Nutrição (PESN) [State Research of Health and Nutrition] as the data source, in 2006, the prevalence rate of overweight observed was $13.3 \% .{ }^{25}$ In addition, in a multicenter research that assessed the nutritional status of school-aged children from the Northeast and Southeast of Brazil identified a prevalence rate of $9.5 \%$ of overweight. ${ }^{26}$ Despite the variations in the prevalence levels of overweight and obesity in the studies indicated, the magnitude of the problems among the school-aged children in our study is clear, as the prevalence of excess weight found is high and demonstrates the need for education and health professionals, families and governments in general to pay attention.

This study was aimed at assessing the factors associated with excess weight among school-aged children and found that higher income was directly associated with the outcome studied. Evidences show that the socioeconomic condition influences this problem, turning into a significant factor associated with the development of overweight. ${ }^{27}$ It should be highlighted that, in developing countries like Brazil, families with higher purchasing power have a greater chance of developing overweight when compared to less well-off families ${ }^{28}$ and that, in less developed regions or states, the proportion of obese people increases with the income. ${ }^{29-30}$ The same trend was observed in Pernambuco, where excess weight was significantly higher among children and adolescents from families with a higher income and a better socioeconomic level..$^{25,31}$ In the South of the country, in Santa Catarina, the results found in a study of students enrolled in the public and private networks were similar to our research, as a significant association was identified between excess weight and income. ${ }^{32}$

Although physical exercise was not associated with overweight in this study, research shows that a higher family income can provide greater access to consumption goods that stimulate sedentariness, like the computer. It is evidenced that greater access to and longer usage time of computers among school-aged children have been associated with sedentariness, which in turn determines overweight and obesity. ${ }^{33}$ Nowadays, a reduction in physical exercise has been observed among children and adolescents. These have engaged in walking increasingly less and use cars more frequently for moving, besides the free consumption of unhealthy products bought in school canteens. ${ }^{34}$

It is highlighted that, in this study, the participants whose mothers had a higher education level had a greater chance of gaining excess weight. Although some studies identify higher maternal education level as a protection factor 
against overweight in children and adolescents, ${ }^{35-36}$ it is interesting that higher maternal education level has also been significantly associated with the habit of TV watching among adolescents, even if that variable was not assessed in this study. ${ }^{37}$ Children and adolescent who watch TV more frequently and longer possibly have a more sedentary behavior and, therefore, are more subject to excess weight. Physically inactive children are at a higher chance of developing overweight and obesity. ${ }^{38}$ It is important to emphasize that overweight children and adolescents tend to maintain this nutritional condition in the adult and elderly phases of life, as the prevalence of these nutritional alterations is increasingly high among elderly people ${ }^{39}$ demonstrating the relevance of actions that minimize this condition since childhood.

Our findings appoint the need for greater efforts from the public power, with a view to the establishment of public nutritional policies, aiming to sensitize and raise the awareness of families, schools and society in general to the importance of avoiding sedentary activities, stimulating physical exercise and healthy eating.

\section{CONCLUSIONS}

This study aimed to assess the factors associated with excess weight (overweight/obesity) in school-aged children enrolled in the municipal public education network of Divinópolis. The results showed a high prevalence of excess weight among the participants, with students whose mothers have a higher education level and who gain a higher family income being more susceptible to overweight and obesity. These findings indicate the need to plan and implement strategies to control these problems, highlighting the importance of a careful approach of children and adolescents in the school environment, mainly in populations with characteristics similar to the research subjects.

As the situation of overweight and obesity represents a public health problem, detailed and periodical nutritional monitoring of the students, health education actions with a view to the promotion of healthy eating and the encouragement of physical exercise are needed. Interventions involving the entire family are proposed, as the actions that are to be implemented should be collective.

Joint and intersectoral efforts from the public power are needed, including the family health program and the school health program, among others, aiming to prevent and reduce the number of cases of excess weight children.

Based on multivariate statistical analysis in a significant sample, this research demonstrates factors associated with excess weight. Its main limitation is the cross-sectional study design, measuring the outcome and exposure simultaneously, without proving the temporality.

\section{REFERENCES}

1. World Health Organization. Obesity and overweight. Fact Sheet Number 311. Geneva (CH): WHO; 2012 May [acesso 2012 Jun 08]. Available from: http:// www.who.int/mediacentre/factsheets/fs311/en/ index.html

2. Instituto Brasileiro de Geografia e Estatística (BR). Informação demográfica e econômica, Indicadores sociodemográficos e de saúde no Brasil. Estudos e Pesquisas. Brasília (DF); 2009 [acesso 2009 Dez 05]. Disponível em: http://www.ibge.gov.br/home/ estatistica/populacao/indic_sociosaude/2009/ indicsaude.pdf

3. Scott JA, Su YN, Cobiac L. The relationship between breastfeeding and weigth status in a national sample of Australian children and adolescents. BMC Public Health. 2012 Fev; 12(1):107.

4. Simon VGN, Souza JMP, Souza SB. Aleitamento materno, alimentação complementar, sobrepeso e obesidade em pré-escolares. Rev Saúde Pública. 2009 Fev; 43(1):60-9.

5. Morley BC, Scully ML, Niven PH, Okely AD, Baur LA, Pratt IS, et al. What factors are associated with excess body weight in Australian secondary school students? Med J Aust. 2012 Fev; 196(3):189-92.

6. Van Rossem L, Silva LM, Hokken-Koelega A, Arends LR, Moll HA, Jaddoe VWV, et al. Socioeconomic status is not inversely associated with overweight in preschool children. J Pediatr. 2010 Jul; 157(6):929-35.

7. Juresa V, Musil V, Majer M, Ivankovic D, Petrovic D. Behavioral pattern of overweight and obese school children. Coll Antropol. 2012 Jan; 36(1):139-46.

8. Felisbino-Mendes MS, Campos MD, Lana FCF. Avaliação do estado nutricional de crianças menores de 10 anos no município de Ferros, Minas Gerais. Rev Esc Enferm USP. 2010 Jun; 44(2):257-65.

9. Pelegrini A, Silva DAS, Petroski EL, Glaner MF. Estado nutricional e fatores associados em escolares. Rev Nutr. 2010 Set-Out; 23(5):839-46.

10. Petribú MMV, Tassitano RM, Nascimento WMF, Santos EMC, Cabral PC. Fatores associados ao sobrepeso e à obesidade em estudantes do ensino médio da rede pública estadual do município de Caruaru (PE). Rev Paul Pediatr. 2011 Dez; 29(4):536-45.

11. Mendonça MRT, Silva MAM, Tassitano RM, Nascimento WMF, Rivera IR, Moura AA. Prevalência 
de sobrepeso e obesidade em crianças e adolescentes da cidade de Maceió. Rev Assoc Med Bras. 2010 Dez; 56(2):192-6.

12. Strufaldi MWL, Silva EMK, Puccini RF. Sobrepeso e obesidade em escolares pré-púberes: associação com baixo peso ao nascer e antecedentes familiares para doença cardiovascular. Embu região metropolitana de São Paulo, 2006. Ciênc Saúde Colet. 2011 Nov; 16(11):4465-72.

13. Gopinath B, Baur AL, Burlutsky G, Mitchell P. Socioeconomic, familial and perinatal factors associated with obesity in Sydney schoolchildren. J Pediatrics Child Health. 2012 Jan; 48(1):44-51.

14. Santos JL, Ho-Urriola JA, González A, Smalley SV, Domínguez-Vásquez P, Cataldo R, et al. Association between eating behavior scores and obesity in Chilean children. Nutr J. 2011 Out; 10:108.

15. Durá-Travé T, Hualde-Olascoaga J, Garralda-Torres I. Exceso de peso corporal infantil en Navarra y su repercusión en la adolescencia. Med Clin (Barc). 2012 Fev; 138(2):52-5.

16. Ramos-Arellano LE, Benito-Damián F, SalgadoGoytia L, Muñoz-Valle JF, Guzmán-Guzmán IP, Vences-Velázquez A, et al. Body fat distribution and its association with hypertension in a sample of Mexican children. J Investig Med. 2011 Out; 59(7):1116-20.

17. Barberán KS, Escala RC, Suco SV. Sobrepeso y obesidad como factores predisponentes de hipertensión arterial en niños de 5 a 12 años en Guayaquil y Nobol. Medicina (Guayaquil). 2011 Out; 16(3):160-8.

18. Wenig CM. The impact of BMI on direct costs in children and adolescents: empirical findings for the German Healthcare System based on the KiGGSstudy. Eur J Health Econ. 2010 Fev; 13(1):39-50.

19. Ministério da Saúde (BR). Protocolos do Sistema de Vigilância Alimentar e Nutricional - SISVAN na assistência à saúde. Brasília (DF): MS; 2008.

20. Ministério da Saúde (BR). Orientações para a coleta e análise de dados antropométricos em serviços de saúde: Norma Técnica do Sistema de Vigilância Alimentar e Nutricional - SISVAN. Brasília (DF): MS; 2011.

21. Hosmer DW, Lemeshow S. Applied Logistic Regression. $2^{\mathrm{a}}$ ed. New York (NY): John Wiley; 2000.

22. Kim B, Park MJ. The influence of weight and height status on psychological problems of elementary schoolchildren through child behavior checklist analysis. Yonsei Med J. 2009 Jun; 50:340-4.

23. Reis CEG, Vasconcelos IAL, Oliveira OMV. Panorama do estado antropométrico dos escolares brasileiros. Rev Paul Pediatr. 2011 Mar; 29(1):108-16.

24. Instituto Brasileiro de Geografia e Estatística (BR). Pesquisa de Orçamentos Familiares: antropometria e estado nutricional de crianças, adolescentes e adultos do Brasil. Brasília (DF); 2010 [acesso 2010 Dez 05]. Disponível em: http://www.ibge. gov.br/home/presidencia/noticias/imprensa/ ppts/0000000108.pdf

25. Leal VS, Lira PIC, Oliveira JS, Menezes RCE, Sequeira LAS, Arruda Neto MA, et al. Excesso de peso em crianças e adolescentes no Estado de Pernambuco, Brasil: prevalência e determinantes. Cad Saúde Pública. 2012 Jun; 28(6):1175-82.

26. Burlandy L, Anjos LA. Access to the school food program and nutritional status of schoolchildren in Northeast and Southeast Brazil, 1997. Cad Saúde Publica. 2007 Mai; 23(5):1217-26.

27. Oyhenart EE, Castro LE, Forte LM, Sicre ML, Quintero FA, Luis MA, et al. Socioenvironmental conditions and nutritional status in urban and rural schoolchildren. Am J Hum Biol. 2008 Jul; 20(4):399405.

28. Gomes FS, Anjos LA, Vasconcellos MTL. Associação entre o estado nutricional antropométrico e a situação sócio-econômica de adolescentes em Niterói, Rio de Janeiro, Brasil. Cad Saúde Pública. 2009 Nov; 25(11):2446-54.

29. Guedes DP, Miranda Neto JT, Almeida MJ, Silva AJRM. Impacto de fatores sociodemográficos e comportamentais na prevalência de sobrepeso e obesidade de escolares. Rev Bras Cineantropom Desemp Hum. 2010 Nov; 12(4):221-31.

30. Freitas JIF, Balikian JP, Miyashita LK, Neiva CM, Isidorio SCA. Crescimento e estado nutricional de crianças e adolescentes de Presidente Prudente, São Paulo, Brasil. Rev Bras Saúde Matern Infant. 2008 Set; 8(3):256-74.

31. Silva JB, Silva FG, Medeiros HJ, Roncalli AG, Knackfuss MI. Estado nutricional de escolares do semi-árido do Nordeste brasileiro. Rev Saúde Pública. 2009 Fev; 11(1):62-71.

32. Ricardo GD, Caldeira GV, Corso AC. Prevalence of overweight and obesity and central adiposity indexes among school-aged children in Santa Catarina, Brazil. Rev Bras Epidemiol. 2009 Set; 12(3):424-35.

33. Corso ACT, Caldeira GV, Fiates GMR, Schmitz BAS, Ricardo GD, Vasconcelos FAG. Fatores comportamentais associados ao sobrepeso e à obesidade em escolares do Estado de Santa Catarina. Rev Bras Estud Popul. 2012 Jun; 29(1):117-31.

34. Guedes DP, Rocha GD, Silva AJRM, Carvalhal IM, Coelho EM. Effects of social and environmental determinants on overweight and obesity among Brazilian schoolchildren from a developing region. Rev Panam Salud Publica. 2011 Out; 30(4):295-302.

35. Fernandes RA, Conterato I, Messias KP, Christofaro DGD, Oliveira AR, Júnior IF. Fatores de risco associados ao excesso de peso entre adolescentes da Região Oeste Paulista. Rev Esc Enferm USP. 2009 Dez; 43(4):768-73. 
36. Fernandes RA, Casonatto J, Christofaro DGD, Ronque ERV, Oliveira AR, Júnior IF. Riscos para o excesso de peso entre adolescentes de diferentes classes socioeconômicas. Rev Assoc Med Bras. 2008 Ago; 54(4):334-38

37. Campagnolo PDB, Vitolo MR, Gama CM. Fatores associados ao hábito de assistir TV em excesso entre adolescentes. Rev Bras Med Esporte. 2008 Jun; 14(3):197-200.

38. Alves JGB, Siqueira PP, Figueiroa JN. Excesso de peso e inatividade física em crianças moradoras de favelas na região metropolitana do Recife, PE. J Pediatr. 2009 Fev; 85(1):67-71.

39. Kümpel DA, Sodré AC, Pomatti DM, Scortegagna HM, Filippi J, Portella MR, et al. Obesidade em idosos acompanhados pela estratégia de saúde da família. Texto Contexto Enferm [online]. 2011 Set [acesso 20 Jun 2012]; 20(3):471-7. Disponível em: http://www.scielo.br/scielo.php?script=sci arttext\&pid $=$ S010407072011000300007\&lng=en 